\title{
XYY syndrome: a 13-year-old boy with tall stature
}

\author{
Won Ha Jo, MD', \\ Mo Kyung Jung, MD', \\ Ki Eun Kim, MD', \\ Hyun Wook Chae, MD', \\ Duk Hee Kim, MD, PhD', \\ Ah Reum Kwon, MD', \\ Ho-Seong Kim, MD, PhD ${ }^{1}$ \\ 'Department of Pediatrics, Severance \\ Children's Hospital, Endocrine \\ Research Institute, Yonsei University \\ College of Medicine, Seoul, \\ ${ }^{2}$ Department of Pediatrics, Sowha \\ Children's Hospital, Seoul, Korea
}

\begin{abstract}
When evaluating the underlying causes of tall stature, it is important to differentiate pathologic tall stature from familial tall stature. Various pathologic conditions leading to adult tall stature include excess growth hormone secretion, Marfan syndrome, androgen or estrogen deficiency, testicular feminization, and sex chromosome anomaly, such as Klinefelter syndrome and XYY syndrome. Men with $47, \mathrm{XYY}$ syndrome can exhibit multiple phenotypes. A 13-year-old boy visited the hospital for evaluation of tall stature. The boy had no other physical abnormalities except tall stature. All biochemical and imaging studies were within the normal ranges. He was diagnosed with XYY syndrome in this chromosome study. When evaluating men with tall stature, XYY syndrome should be ruled out.
\end{abstract}

\section{Keywords: Growth disorders, Sex chromosome disorders, 47,XYY syndrome}

\section{Introduction}

Tall stature is defined as a height that is above the 97th percentile for an individual's age and sex, and should be considered a pathologic underlying disease if it is not a familial (or normal variant constitutional) tall stature. Various pathologic conditions can cause tall stature, such as excess growth hormone $(\mathrm{GH})$ secretion, precocious puberty, obesity, pituitary tumor, Marfan syndrome, and homocystinuria ${ }^{1)}$. Additionally, the sex chromosome anomaly such as Klinefelter syndrome results in tall stature. Another sex chromosome anomaly, XYY syndrome, can also cause tall stature.

Although the karyotype 47,XYY is relatively common, observed in 1 in every 1,000 live male births, the 47,XYY syndrome and its phenotypes are not well-understood ${ }^{2}$. Additionally, there are no specific clinical manifestations in most boys with the XYY karyotype. Diagnosis of an XYY karyotype is delayed (mean age at diagnosis is 17.1 years) and only $15 \%$ of patients are diagnosed with XYY syndrome ${ }^{3-5)}$. A few studies have reported that the phenotype of XYY syndrome includes physical abnormalities such as tall stature and behavioral and psychiatric problems, such as attention deficit hyperactivity disorder (ADHD) and autism spectrum disorder $(\mathrm{ASD})^{4,6}$. Learning difficulties and delayed language skills have been associated with XYY syndrome. However, methods for precisely evaluating and treating XYY syndrome have not been established. Therefore, a comprehensive understanding of the clinical manifestations of XYY syndrome is required.

Here, we report the case of a male child with XYY syndrome diagnosed during tall stature evaluation. We also review the literature discussing the XYY syndrome with possible multiple phenotypes.

\section{Case report}

A 13-year-old male patient visited Severance Children's Hospital for assessment of his tall stature. He was born large for the gestational age with a birth weight of 4,000 $\mathrm{g}$ at 40 weeks by vaginal delivery. He did not have any remarkable medical history or family history. His father's height was $188 \mathrm{~cm}$ (above the 97th percentile), his mother's height was $164 \mathrm{~cm}$ (between

Fax: +82-2-393-9118

E-mail:kimho@yuhs.ac 
the 50th and 75th percentiles), and the midparental height is $182.5 \mathrm{~cm}$ (between the 90th and 95th percentiles). At physical examinations, his height and weight were $184.4 \mathrm{~cm}$ (above the 97 th percentile) and $78 \mathrm{~kg}$ (above the 97th percentile), respectively. His body mass index was $22.94 \mathrm{~kg} / \mathrm{m}^{2}$ (between the 75th and 90th percentiles). He was found to have a Tanner pubertal stage of P3 with testicular volumes of $10 \mathrm{~mL}$ in both testicles. We found no signs of Marfan syndrome, such as wrist sign or thumb sign. Pes cavus, genu valgum, pectus excavatum, or pectus carinatum which can be seen in homocystinuria, were also not observed.

The complete blood count, routine chemistry, and urine analysis results were normal. His thyroid function test was also normal (free T4, $1.08 \mathrm{ng} / \mathrm{dL}$ [normal range, $0.70-1.48 \mathrm{ng} / \mathrm{dL}$ ]; thyroid-stimulating hormone, $2.28 \mu \mathrm{IU} / \mathrm{mL}$ [normal range, $0.35-4.94 \mu \mathrm{IU} / \mathrm{mL}])$. Insulin-like growth factor I (IGF-I) and insulin-like growth factor binding protein-3 (IGFBP-3) were normal for the sex and age (IGF-I, $361.5 \mathrm{ng} / \mathrm{mL}$ [normal range, 118.4-677.5 ng/mL]; IGFBP-3, $2.46 \mu \mathrm{g} / \mathrm{mL}$ [normal range, $1.5-4.4 \mu \mathrm{g} / \mathrm{mL}])$. Oral glucosed tolerance test was performed to evaluate GH excess and GH was suppressed successfully, to less than $0.1 \mathrm{ng} / \mathrm{mL}$. To evaluate homocystinuria and other metabolic diseases, tandem mass and urine organic acid tests were performed, and the results were normal. In imaging studies, the patient's bone age was consistent with his chronological age, and his predicted adult height was approximately $200 \mathrm{~cm}$ according to the Greulich and Pyle method. Sella magnetic resonance imaging showed normal results except for a Rathkes cleft cyst about $2 \mathrm{~mm}$ in length detected in the pars intermedia. Echocardiogram and the visual field analysis were also normal. These results enabled us rule out Marfan syndrome, along with the lack of family history and specific clinical features of Marfan syndrome. The chromosome test results showed a 47,XYY karyotype (Fig. 1). Given these results, it was assumed that the patient has $47, \mathrm{XYY}$ syndrome.

The patient will be followed up in an outpatient clinic to monitor Rathke's cleft cyst. Developmental status and peer relation appear to be normal, but for further evaluation and psychiatric consultation are planned to assess the patient's psychological status. Consultation is also planned for genetic counseling.

\section{Discussion}

Some children are referred for evaluation because of concerns regarding their tall stature. Some of the children who

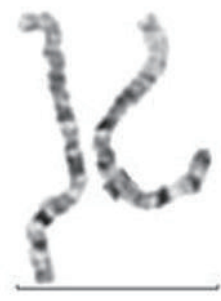

1

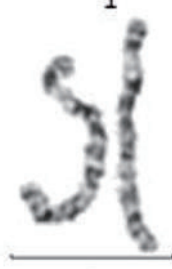

6

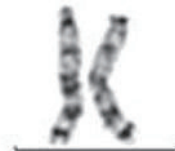

13
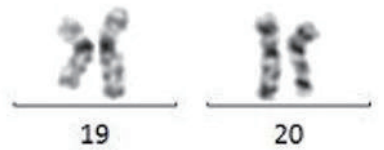

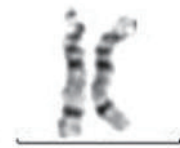

14

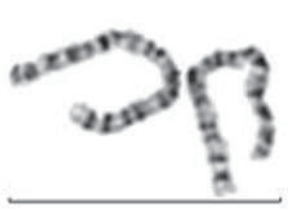

2

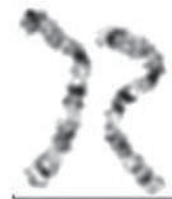

7

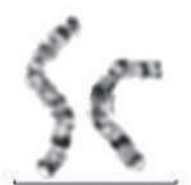

8

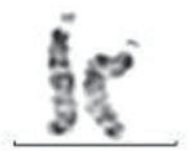

15

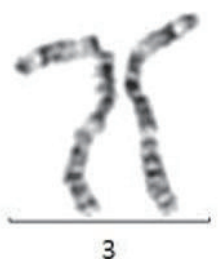

3

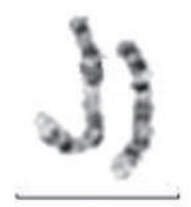

9

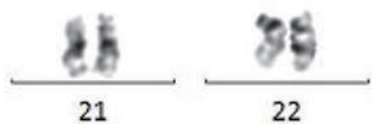

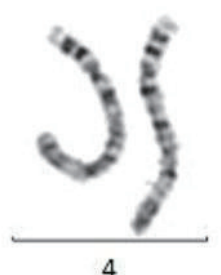
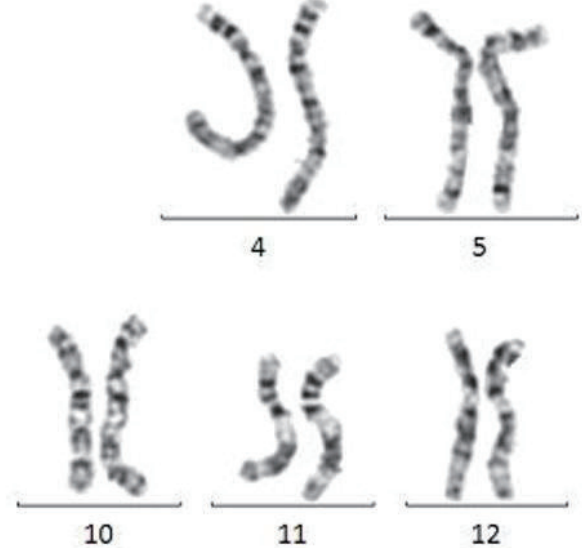

12

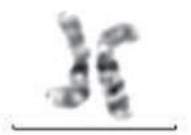

16
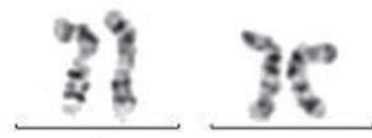

18
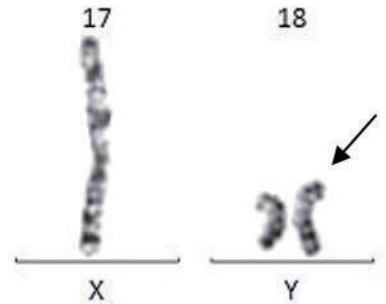

Fig. 1. Result of chromosome study of a 13-year-old boy showing 47,XYY karyotype (arrow indicates the extra Y chromosome). 
Table 1. Summary of previous reports about clinical features and comorbidities in 47, XYY syndrome

\begin{tabular}{|c|c|c|c|c|}
\hline Source & Age (yr) & Height/weight & Comorbidity & Conclusions \\
\hline \multirow[t]{3}{*}{ Kim et al. ${ }^{14)}(n=3)$} & 37 & $\begin{array}{l}190 \mathrm{~cm} \text { (>97th percentile)/ } \\
180 \mathrm{~kg} \text { (>97th percentile) }\end{array}$ & $\begin{array}{l}\text { Oligoasthenoteratozoospermia, } \\
\text { Tourette syndrome }\end{array}$ & $\begin{array}{l}\text { Men with 47, XYY syndrome will likely } \\
\text { have decreased fertility potential. }\end{array}$ \\
\hline & 27 & $\begin{array}{c}198 \mathrm{~cm} \text { (>97th percentile)/ } \\
151 \mathrm{~kg} \text { (>97th percentile) }\end{array}$ & $\begin{array}{l}\text { Oligospermia, obstructive sleep apnea, } \\
\text { asthma }\end{array}$ & \\
\hline & 35 & $\begin{array}{c}193 \mathrm{~cm} \text { (>97th percentile)/ } \\
139 \mathrm{~kg} \text { (>97th percentile) }\end{array}$ & Oligozoospermia & \\
\hline \multirow[t]{2}{*}{ Margari et al. ${ }^{6}(n=2)$} & 3.5 & $\begin{array}{l}90 \mathrm{~cm} \text { (50th percentile)/ } \\
13 \mathrm{~kg} \text { (50th percentile) }\end{array}$ & ASD & $\begin{array}{l}\text { There is a possibility of association } \\
\text { between ASD and XYY syndrome. }\end{array}$ \\
\hline & 2.5 & $\begin{array}{l}83 \mathrm{~cm} \text { (50th percentile)/ } \\
11.8 \mathrm{~kg} \text { (50th percentile) }\end{array}$ & ASD & \\
\hline Kasparis et al. ${ }^{10)}(n=1)$ & 3 & N/A & $\begin{array}{l}\text { Acne, congenital hypoplastic aortic arch, } \\
\text { large ventricular septal defect, ASD }\end{array}$ & \\
\hline Bardsley et al. ${ }^{8)}(n=90)$ & $9.6 \pm 5.3^{\mathrm{a})}$ & $\begin{array}{c}\text { Height } 1.0 \pm 1.2^{\mathrm{a})} \\
\text { (height }>2 \mathrm{SD} \text { in } 15 \%) / \mathrm{N} / \mathrm{A}\end{array}$ & $\begin{array}{l}\text { Hypotonia in 57/90 (59\%), clinodactyly } \\
\text { in } 47 / 90(52 \%) \text {, macroorchidism in } 41 / 82 \\
(50 \%) \text {, asthma in } 35 / 89(39 \%) \text {, seizure in } \\
12 / 89(13 \%) \text {, ASD in } 26 / 90(29 \%)\end{array}$ & $\begin{array}{l}\text { The XYY phenotype includes tall stature, } \\
\text { macroorchidism, hypotonia. There was } \\
\text { an increased incidence of asthma, } \\
\text { seizure and ASD. }\end{array}$ \\
\hline
\end{tabular}

ASD, Autism spectrum disorder; N/A, not applicable; SD, standard deviation.

a) Data are expressed as mean \pm SD.

have familial tall stature may not require treatment. However, when assessing children with tall stature, various pathologic conditions should be evaluated. GH excess, hyperthyroidism, precocious puberty, and overgrowth syndromes are known causes of tall stature ${ }^{1)}$. Sex chromosome anomalies such as Klinefelter syndrome and XYY syndrome are also known to cause tall stature and should be considered.

Few case reports and studies have been published regarding the characteristics of XYY syndrome (Table 1). XYY syndrome is a sex chromosome variation in which males have a $47, \mathrm{XYY}$ karyotype due to an additional Y chromosome. This 47,XYY karyotype results from parental nondisjunction during the second meiotic division ${ }^{7}$. Although most men with XYY syndrome are not diagnosed ${ }^{4)}$, boys with the 47,XYY karyotype may have various phenotypes. In a cohort study conducted by Bardsley et al. ${ }^{8)}$, boys with the XYY chromosome usually have tall stature starting at the age of approximately 6 years. Although the exact cause of tall stature remains unknown, an extra copy of the short stature homeobox gene may be associated with tall stature ${ }^{9}$. In addition, various physical phenotypes in men with XYY syndrome may be observed, such as macrocephaly, macroorchidism, hypotonia, hypertelorism, and tremor ${ }^{8)}$. Other phenotypes, such as acne, atopy, and asthma, have also been associated with XYY syndrome ${ }^{8,10}$. Such phenotypes have been associated with an extra $\mathrm{Y}$ chromosome, although this remains unclear. The patient in our case showed only tall stature without any other phenotypes and physical features.

Few studies have addressed fertility in men with XYY syndrome. The sperm count in men with XYY syndrome ranges from normal to azoospermia ${ }^{11)}$. Spermatogenesis impairment caused by an extra Y chromosome during meiosis has been reported ${ }^{12)}$. The incidence of chromosomally abnormal spermatozoa in the semen is increased in men with XYY syndrome ${ }^{7}$. Hyperhaploid sperm may pass an extra $Y$ chromosome to the offspring ${ }^{13)}$. In a review of three cases by
Kim et al. ${ }^{14)}$, men with $47, \mathrm{XYY}$ syndrome likely had decreased fertility. The present patient was not subjected to sperm analysis, and this will be evaluated at a later time if needed.

Psychiatric evaluation of men with XYY syndrome should also be conducted. A cohort study performed by Bardsley et al. ${ }^{8)}$ revealed a higher prevalence of ADHD and ASD in men with XYY syndrome, which is consistent the results of another study ${ }^{6}$. Since the prevalence of ADHD is much higher in men than in women, it is thought to be associated with the Y chromosome. Approximately one-third of boys with XYY syndrome are diagnosed with ASD, while the prevalence is $1 \%$ in the general population ${ }^{8}$. However, the relationship between the extra $Y$ chromosome and psychiatric issues is not well understood. When XYY syndrome is diagnosed, psychiatric evaluation should be planned; we plan to examine our patient for neuropsychiatric development, including cognitive function and mood.

$\mathrm{XYY}$ syndrome is rare, but men with an XYY chromosome may show no abnormal features except tall stature. When predicted adult height is much higher than midparental height, exams should be conducted to rule out pathologic tall stature including XYY syndrome. If the tall stature in a patient is caused by an XYY karyotype, psychiatric status, infertility, and other nonspecific symptoms should be evaluated.

\section{Conflict of interest}

No potential conflict of interest relevant to this article was reported.

\section{References}

1. Sabin MA, Werther GA, Kiess W. Genetics of obesity and overgrowth syndromes. Best Pract Res Clin Endocrinol 
Metab 2011;25:207-20.

2. Jacobs PA, Melville M, Ratcliffe S, Keay AJ, Syme J. A cytogenetic survey of 11,680 newborn infants. Ann Hum Genet 1974;37:359-76.

3. Ratcliffe S. Long-term outcome in children of sex chromosome abnormalities. Arch Dis Child 1999;80:192-5.

4. Children and young adults with sex chromosome aneuploidy: follow-up, clinical and molecular studies. Minaki, Ontario, Canada, June 7-10, 1989. Birth Defects Orig Artic Ser 1990;26:1-304.

5. Stochholm K, Juul S, Gravholt CH. Diagnosis and mortality in 47,XYY persons: a registry study. Orphanet J Rare Dis 2010;5:15.

6. Margari L, Lamanna AL, Craig F, Simone M, Gentile M. Autism spectrum disorders in XYY syndrome: two new cases and systematic review of the literature. Eur J Pediatr 2014; 173:277-83.

7. Wong EC, Ferguson KA, Chow V, Ma S. Sperm aneuploidy and meiotic sex chromosome configurations in an infertile XYY male. Hum Reprod 2008;23:374-8.

8. Bardsley MZ, Kowal K, Levy C, Gosek A, Ayari N, Tartaglia N, et al. 47,XYY syndrome: clinical phenotype and timing of ascertainment. J Pediatr 2013;163:1085-94.

9. Ottesen AM, Aksglaede L, Garn I, Tartaglia N, Tassone F, Gravholt $\mathrm{CH}$, et al. Increased number of sex chromosomes affects height in a nonlinear fashion: a study of 305 patients with sex chromosome aneuploidy. Am J Med Genet A 2010;152A:1206-12.

10. Kasparis C, Loffeld A. Childhood acne in a boy with XYY syndrome. BMJ Case Rep 2014 Jan 6 [Epub]. http://dx.doi. org/10.1136/bcr-2013-201587.

11. Rives N, Milazzo JP, Miraux L, North MO, Sibert L, Mace B. From spermatocytes to spermatozoa in an infertile XYY male. Int J Androl 2005;28:304-10.

12. Milazzo JP, Rives N, Mousset-Simeon N, Mace B. Chromosome constitution and apoptosis of immature germ cells present in sperm of two 47,XYY infertile males. Hum Reprod 2006;21:1749-58.

13. Lim AS, Fong Y, Yu SL. Analysis of the sex chromosome constitution of sperm in men with a 47, XYY mosaic karyotype by fluorescence in situ hybridization. Fertil Steril 1999;72:121-3.

14. Kim IW, Khadilkar AC, Ko EY, Sabanegh ES Jr. 47,XYY Syndrome and Male Infertility. Rev Urol 2013;15:188-96. 